\title{
How to do things with jokes: Speech acts in standup comedy
}

\section{Debra Aarons}

University of New South Wales

d.d.aarons@unsw.edu.au

\section{Marc Mierowsky}

Keele University

M.B.Mierowsky@keele.ac.uk

\begin{abstract}
In How to Do Things with Words (1962), the philosopher John Austin claimed that we use words to do things in the world, not merely to express a state of affairs. This proposal introduced speech acts, and essentially initiated the study of linguistic pragmatics. Speech acts in everyday communication include persuading, apologizing, criticizing, humiliating, complimenting and a host of other intended behaviours. Austin accentuated the idea of speaker intention, on one hand, and hearer's response to that intention if successfully conveyed, on the other. We consider some of the speech acts used in the work of selected standup comedians to analyse the way they determine the relationship of performer and audience. We argue that there is a reciprocal relationship between the licensing of certain speech acts in standup comedy, and the success of these speech acts in shaping the social lives of the audience. We show that this relationship is at the forefront of standup comedy's social impact and that it can generate heightened consciousness of the social and political environment of the time. Finally, we consider the question of whether socially critical standup can have any noticeable effect on the attitudes or behaviour of both live and digitally mediated audiences.
\end{abstract}

Keywords: comedian, persona, play frame, performance, standup, speech act. 


\section{Introduction}

In this article, we outline the basic principles of Speech Act Theory as conceived by John Austin (1962). We explicate the idea that human communicative interaction is not simply an exchange of true or false statements about the world, but instead, that when we use language, we do things with words. We explore some Speech Acts used by a small selection of standup comedians to show how they function as an open-ended set of strategies designed to create a relationship with the audience. In doing so, we place this relationship between the comedian and the audience at the forefront of standup comedy's social impact, interrogating the idea that socially critical standup can generate heightened consciousness of the social and political environment of the time. Taking as our basic premise the idea that when standups use a stage to talk directly to the audience, it is generally, to mobilise them in some way- whether to get them onside or offside-we make the case that these standup performers use the complex communicative context of the comedy performance as a way of getting people to do things in the world.

\subsection{Speech acts}

Moving away from the idea that we use language simply to make assertions or ask questions, Austin introduced the concept of Speech Acts; that is, the idea that we use utterances to do things in the world. The first major observation Austin made is that utterances always occur in a context. Context is a coverall term for the interweaving of many different aspects of a communication situation. At the least, a conversational context comprises a speaker, a hearer, a place, a time, a topic or some content, a relationship between the participants, a set of background assumptions that may or may not be shared and some taken for granted knowledge of the world. Additionally, part of the "taken for granted" assumptions is a shared knowledge of the language and the uses that different forms of language can be put to. Austin emphasised the idea of speaker intention, on one hand, and listener's response to that intention if successfully conveyed, on the other. Although crucial to Austin's original conception of speech acts is the notion of speaker intention, known now as the illocutionary force of the utterance (Austin 1962), subsequent scholars have explored the process by which hearers identify speakers' intention, naturally using their sense of the shared context of the interaction. For example, essential in understanding the Speech Act involving the uttering of the word "Fire!" is grasping the speaker's intention. That in turn depends on an understanding of the context of utterance. Is it issued by the leader of the execution squad, an usher rushing into a crowded cinema, or someone having swallowed an excruciatingly hot chili pepper? The response of the hearer/s, accordingly, is based on an understanding of the speaker's intention. Since the publication of How to do things with words, a vast body of scholarship has grown up around Austin's ideas which, in turn, have been changed, developed, adopted, adapted, challenged and have also taken on lives of their own (see particularly, Searle 1969, 1979). While this progression is beyond the scope of this article, it is worth drawing attention to one crucial aspect of Speech Act Theory: the idea that the hearer's recovery of the speaker's intention is fundamental to the success or otherwise of the speaker's intention. It is this aspect of Speech Act Theory-the perlocutionary success of the speaker's intention - which is left open to speculation in this article. ${ }^{1}$

\subsection{Speech acts in standup comedy}

In order to analyse the way speech acts shape the relationship of performer and audience, we first outline the speech event (Austin 1962) common in all standup. Obviously, the overall 
purpose of standup is to entertain the audience. That is the implied contract. The audience agrees to give the performer licence and the performer takes that licence. The contract is by no means permanent as the audience may remove that licence at any time: if the performer isn't good enough, the audience may boo them off the stage; if the performer offends the sensibilities of the audience, the audience may revolt in some way. As Rebecca Krefting notes, and this indeed is taken for granted by any comedian worth their salt, "Rule number one in writing comedy: a joke is only funny when the listener shares the comic frame being created by the comic." Successful comics, as Krefting goes on to demonstrate, invoke frames of reference familiar to as large a proportion of the audience as possible, taking recourse from the fact that "many things unite a group of strangers assembled together" (Krefting 2014: 202).

The implied contract is arguably clearest at its stress points, one of them being the intrusion of hecklers. If, for instance, a heckler gets out of control and the performer cannot get the audience back, the licence expires. There are some intriguing and differing examples of performers dealing with hecklers, and these can be contrasted with the relationships between performer and audience that do go according to plan. ${ }^{2}$

Fundamental to analysing the context of any utterance is a consideration of who is speaking. With standup comics, we have to take into consideration a set of concomitant concerns: is it a persona or the performer in her own voice? Who is the audience, and what is the speaker's intention in making the utterance in question? Is it to embarrass, enjoin, criticize, tease, disgust, incite or perhaps simply to amuse the audience? The narrow context of the speech event is the standup stage, but the time and place in history is an important contributory factor in socially critical standup. Also, of course, the delivery, timing, intonation and physical performance are all interwoven in the success of the particular speech event; in this case, the standup routine. Standup is not really reciprocal turntaking. The audience response is expected to be laughter, rather than speech. Notably, in modern standup, there is no restriction on the length of utterances. This is a structural change in the history of standup. In the days of the quick-fire one-liners, jokes were fast with no response other than laughter expected from audience.

In modern standup, the persona of the performer is all-important, especially in that the performer has a constant, predictable persona. When audiences attend a standup's performance, they know more or less what they are going to get. It is of importance in today's standup world that a performer in persona has a history. This is part of the context: a comedian who is notorious for a misogynistic or racist persona carries this over into performance. Standup is often called improv, but it seldom is fully improvised. As a rule, the best performers are extremely well-prepared, have crafted a persona through which they engage the world and are, in the guise of this persona, ready for most eventualities. ${ }^{3}$

Standup performers often begin with a welcome to their audiences, "How're you all doing, Sydney?" (or whatever the appropriate place name). Of course, they don't really want to know. It is a strategy to initiate the relationship: the performer cares, the audience feels acknowledged. This tried and tested technique captures in brief how reliant modern comics are on opening channels of communication with their audiences. Much of today's standup performances are essentially storytelling, and the relationship of performer to audience is that of narrator to listener. However, some standups are quite abrasive towards their audiences, their speech acts designed with the intention of persuading the audience of a certain injustice, by whatever means. This sort of standup has been extensively described and ingeniously labelled by Rebecca Krefting as "charged humor" (Krefting 2014: 25ff).

The rest of this article is an investigation into how a reciprocal relationship between the licensing of certain speech acts in standup comedy is achieved. Tentatively, we speculate on 
the success of these speech acts in shaping the consciousness, both individual and political, of the audience.

\section{The performers}

Most verbal humour, we can take for granted, is culturally specific, in that some things will be regarded as funny in some cultures and not others. Here we offer four case studies. All are from the United States, as this is a culture widely consumed, certainly in the Englishspeaking world. The performers we have selected are Hari Kondabolu, a standup comedian of Indian origin, born and raised in the US and well known for his socially critical standup, much of it to do with race, social norms, class and gender. Thea Vidale, our second example, is an African-American woman who has had a long career as a standup comedian, beginning in 1986. She has continued to do standup while performing in sitcoms and films and appearing on various talk shows. Her work is generally concerned with race, LGBT rights, and domestic violence. Lenny Bruce, the third case, is universally acknowledged as one of the figures most responsible for modern standup of the critical, abrasive, persona-driven kind. He was a Jewish American comedian, most active in the early 1960s. He was arrested and tried for obscenity on a number of occasions and is regarded by many as having been martyred for his views on freedom of expression. His work was geared against hypocrisy, racism, censorship, police brutality and suppression of individual freedom. Bruce died of a heroin overdose in 1966 and has since been immortalized by many standup comedians who acknowledge him as their inspiration and role model. Our final case study is Daniel Tosh. Tosh is a white male American comedian, born in 1975, well-known for being very edgy and proudly politically incorrect. Many of his performances are concerned with sexism, racism, homophobia and Islamophobia.

\subsection{Hari Kondabolu — an honest moment in Aspen}

In this clip, Hari Kondabolu is performing a routine at the Wheeler Opera House in Colorado. ${ }^{4}$ He addresses the audience in the second person, and speaks directly to them. This is not a narrative, although he keeps pretending he's going to tell them a story. What he does here is interesting because he plays with the two conventions while drawing attention to the fact that he's doing so. He is addressing an audience of predominantly white people in Aspen, Colorado, a place where people go to ski, and he is addressing them as though they are all white and comfortably upper middle-class.

So this... has been interesting Aspen...Uh

I've been here before. This time it's not snowing. That's good, cause last time it was snowing and this of course is a city so white that when it snows you can't find anybody (audience laugh). So it was nice to know I could actually see people (audience laugh). No its ok, it's ok Aspen, you can take it a little bit, it's ok, we're going to be ok, just remember... this is smart Aspen, this is smart, like hiding yourself on this little mountain, this is good so when the revolution comes people won't be able to get up here (audience laugh and clap). So that's good, that's good Aspen, it's smart, it's smart that you've hid up here, of course the bottom of the mountain will be armed so supplies won't go up so you'll starve to death but until the revolution comes you are safe Aspen (audience laugh). For those of you who don't know what the revolution is, (audience laugh) you will (audience laugh).

Went bowling the other night. (audience laugh). Just with a segue like that, I'll pretend, I'm going to pretend that I didn't just tell an audience full of mostly white, a good percentage with wealth, that they would die violently in a revolution that will honestly never come. What will come of course is a catastrophic catastrophe. That's the same thing twice that (audience laugh) 
environmental ... uh we'll all die together and wealth will mean nothing when we go the way of the dinosaurs. Look this is what's going to happen. The truth is ... I am God (audience laugh) and it's very hard to ... and I didn't think I would take this form (audience laugh) ... uh as a rambling comedian uh who wasted his education, this is not what I expected out of my time here but I'm telling you now, you need to run (audience laugh). Should we keep going? Ok I'm in this bowling alley laughter and ... at some point in the last five years I was in the bowling alley...

There are several strategies that Kondabolu uses that may be seen as speech acts in which he addresses the audience directly. He plays with the pronouns I and you, drawing a distinction between himself as the performer and the audience as a whole. He talks to the audience as "Aspen", constructing them as a unified entity, at the same time constructing his own persona-a rather silly young man laughing at his own cheek. However, once he settles down, his first speech act is to reassure the audience "It's ok, Aspen, it'll be ok", "it's ok, you can take it...". On the face of it, the speech act here is reassurance. However, indirectly, he is threatening them (in jest, we can assume) with the revolution. The fact that he can issue this threat is the shared assumption, also created by his use of naming strategies, that because they are white, and he is not, he is the representative of the revolutionary forces, and is here both to warn them, but also calm them, because, "it won't be too bad". Each time, after he says, "it will be ok," and "you'll be safe," he introduces a new terrifying threat. In using these speech acts, the persona pretends that he can actually control how bad the situation will be. His intention, as persona, is to assure the audience of his power in controlling the disasters that are to befall them. He includes little asides, speech acts that sound as if he is providing useful information, such as, "For those of you who don't know what the revolution is, you will," thus issuing the speech act of insult (suggesting that as they have lived their protected lives as whites in the land of ski resorts they have little knowledge of the real world). Yet again, he reverts to reassurance, "but don't worry, you're safe...you won't die violently in a revolution which will never come..." rather, he warns of a catastrophe, and advises them, "you need to run". Eventually, he claims to be God, at which point, even he cannot sustain the scenario he has constructed.

This routine is carefully designed to be playful. There's a play frame: he's pretending that he is bringing a message to the people at the top of the mountain, from the masses at the bottom. He draws attention to the possibility that they may take offence, and plays on the social currency that one should be able to 'take a joke' - a basic aspect of modern sociability. The audience allows him this play, accepting his construction by laughing. The persona's pretence that he is uncertain about the comedy he is doing and whether he should rather be telling a clichéd story about a bowling alley shows the complete consciousness of the performer who knows what he is doing and the conventions he is playing with. From what we can gather, the audience came to see him, laughed uproariously and took the insults with good humour. At the same time, however, he pointedly highlighted some complex class and race issues, although there is very little obvious aggression, despite the exaggerated threats from on high. We cannot know what his actual intentions were, but we can safely say from the performance we see, that he hits his targets. Whether there is any follow-up on the part of his audience, we can't know. So, this rather gentle, teasing performance, in which the direct speech acts are hubristic and omnipotent and at the same time undercut by self-mockery, nevertheless contain other, more indirect acts. Besides the reassurance, the chivvying to be brave, Kondabolu is pointing out to his audience the precarious and fearful consequences of privilege. Despite the direness of his threats, his persona is gentle, jovial and teasing. 


\subsection{Thea Vidale on Osama Bin Laden}

In contrast, the following transcript is taken from the appearance of Thea Vidale an AfricanAmerican American comedian on the Tavis Smiley Show, in 2002. This was within a year of the $9 / 11$ tragedy. She said,

Osama Bin Laden-He ain't mad at us. He mad at y'all ... America was shocked 'cause it's not so much that we got bombed -it's where they bombed us. They bombed us at the World Trade Center ... You know, 'cause if it had been ... Compton ... or Harlem, they would've been saying, "Osama Bin Laden has bombed Compton, California and Harlem, New York. Next, Jim with Sports ..."

Apart from the shock value, in part because of how recently the event took place, if we analyse the way she uses pronouns here, we can see how she divides the audience. She identifies Osama as he, and uses y'all to refer to white Americans. However, she talks about we and us in an interesting way.

She says first off, "He ain't mad at us" Because of the y'all that follows, the us clearly refers to black people. Then she refers to America as a whole as we. "America was shocked 'cause it's not so much that we got bombed, it's where they bombed us. They bombed us at the World Trade Center." Here Osama Bin Laden is referred to as they. These two uses of they make a clear contrast between us, the American people as a whole, and the bombers. Following this, though, she switches to they in an interesting way. "...they would have been saying...". They now refers to the mainstream news media, and shows the distancing from both we and you.

So, if we were to replace all these pronouns with full nouns, the text of her routine would read as follows:

Osama bin Laden — ain't mad at black people. Osama bin Laden mad at all you white people ... America was shocked 'cause it's not so much that America got bombed-it's where Osama bin Laden and company bombed America. Osama bin Laden and company bombed America at the World Trade Center ... You my audience know, 'cause if it had been ... Compton ... or Harlem, the mainstream media would've been saying, "Osama Bin Laden has bombed Compton, California and Harlem, New York. Next, Jim with Sports ..."

To unpack this, it's worth looking carefully at her speech act behaviour, that is her intentions. Firstly, she's obviously making a distinction between we (inclusive) and we exclusive, i.e. we all and we, not you. She plays with this: so, we (inclusive) is an attempt to draw America as one, but probably means that when the World Trade Center is bombed, the governing assumption is that this is an attack on all of America, but when Compton or Harlem is bombed, this is not an attack on all of America, but on a subsection, the strong implication being that these are predominantly centres of less empowered black people, and thus not as central to the idea of America as conceptualised in news reports.

The overall intention of Vidale's remarks is to goad people into thinking about how they conceptualise America as a whole, and question their taken for granted assumptions about what is important. Her characterization of the order of the news is that the sports report is likely to be the next item after hypothetical bombing, and thus that a bombing in ghettoized areas is of lesser importance.

As part of achieving this overall intention, she uses accusation. This is an indirect speech act, as there is no overt syntactic or semantic evidence for such an interpretation, but the intention is made clear by all the features of the context that are brought to bear on the utterance. The accusation is that some parts of her audience have a naturalised world view 
that sees America as essentially white. Her intention is to highlight this unconscious assumption and to point out that there is a certain blindness of which most of us are culpable.

So, in this example, we see that in a very small piece of standup, despite the overall purpose of entertainment or amusement, there is a great deal of political and social critique as well as an intention to spur the audience on to a more nuanced understanding of a particular mainstream phenomenon. Vidale does not use the words race or class or religion. But all these ideas are planted by her clever use of pronouns (particularly) that create different forms of divisiveness and unity, triggering, in this case, speech acts of accusation and provocation.

\subsection{Lenny Bruce - Are there any niggers here tonight?}

Continuing the topic of race and divisions, the following is an audio recording of Lenny Bruce, a classic in the field of standup. The recording was made in 1964 at a small comedy club. ${ }^{5}$

... By the way, are there any niggers here tonight?

[Outraged whisper] "What did he say? 'Are there any niggers here tonight'? Jesus Christ! Is that cruel. Does he have to get that low for laughs? ..."

Are there any niggers here tonight? I know that one nigger who works here, I see him back there. Oh, there's two niggers, customers, and, ah, aha! Between those two niggers sits one kike-man, thank God for the kike!

Uh, two kikes. That's two kikes, and three niggers, and one spic. One spic-two, three spics. One mick. One mick, one spic, one hick, thick, funky, spunky boogey. And there's another kike. Three kikes. Three kikes, one guinea, one greaseball. Three greaseballs, two guineas. Two guineas, one hunky funky lace-curtain Irish mick. That mick spic hunky funky boogey. Two guineas plus three greaseballs and four boogies makes usually three spics. Minus two Yid spic Polack funky spunky Polacks.

(Assumes persona of AUCTIONEER): Five more niggers! Five more niggers!

Assumes persona of GAMBLER): I pass with six niggers and eight micks and four spics.

The point? That the word's suppression gives it the power, the violence, the viciousness. If President Kennedy got on television and said, "Tonight I'd like to introduce the niggers in my cabinet," and he yelled, "niggerniggerniggerniggerniggerniggernigger" at every nigger he saw, "boogeyboogeyboogeyboogeyboogey niggerniggerniggernigger" till nigger didn't mean anything anymore, till "nigger" lost its meaning, you'd never make any four- year-old nigger cry when he came home from school...

This routine was performed a few times, but originally in a small nightclub in 1964. Generally speaking, the audiences at Lenny Bruce performances knew what they were going to get. Very often there were also police in the audience, waiting for him to do something for which they believed they could arrest him. Here he exploits the contrast between the persona and the comedian who has a very serious point to make. The persona oscillates in this routine. There is Bruce the persona, using as many racist epithets as he can summon for the various American ethnicities that are singled out. There is also Bruce the neologist (as he liked to call himself, a man who thought language use needed some radically explosive treatment) and Bruce the moral critic.

The overall obvious speech act in this routine is offensive name-calling. Whereas the overt intention of the persona can be read as insulting, humiliating, reducing, maligning, deriding and stereotyping, this is precisely not the speech act the comedian intends and not the effect on the audience that he has planned. The intention of the comedian is to completely defuse the power of racist terminology. Bruce was the first standup comedian to do this. Others have subsequently bombed very badly when they have tried the same stunt, because they either did not read their audiences correctly or were not as much in control of their 
routines. Bruce knew exactly what he was doing. When he addresses his audience in this routine, he first uses the speech act of singling out and separating out the different ethnicities by issuing a whole lot of racist slurs. This listing soon becomes ridiculous, as it turns seamlessly into a routine in which the speech act is auctioneering. He assumes the persona of an auctioneer (reminiscent of slave auctions in the earlier period of US history), and then just as seamlessly he shifts into the discourse of a gambler trying to outbid an opponent. At this point, to an audience even halfway prepared for Bruce, knowing of his infamous reputation, the routine becomes hilariously ludicrous. The point is already made: these naming slurs are preposterous, farcical and absurd. Then Bruce, who actually saw himself as something of a prophet, spells out his point, using the speech act of explanation, one not often used in contemporary standup, as it turns out. When words are suppressed, he says, they are given especial power, because if we suppress the words, we suppress the opportunity of talking about the iniquitous issues they cover. And if anything is taboo or suppressed it becomes very powerful indeed. His speech act, when he says, "nigger nigger nigger...", is designed to show that words are parts of utterances, and the speaker's intention in making the utterances is much more important than the words themselves. When he repeats them enough, in that context, their power completely disappears.

The overall speech act of this routine is to shock, and then to instruct. Bruce was a moralist, despite the fact that he is remembered as the most outrageous, blasphemous and obscene comic of his day. His intention here was to highlight for his audience the power of people and their own control over language to break the bonds and intimidation of taboos. He blows up hypocrisy by defying and defusing these taboos. History has shown that it takes great professionalism and control to shock as Bruce did, yet remain on the right side of the issue.

\subsection{Daniel Tosh - At least we're not women, right fellas?}

Daniel Tosh, somewhat notorious for what he calls "telling it like it is", focuses in his standup on sexism, racism, homophobia and Islamophobia. Although he claims not to be espousing the views he expresses, he admits that he finds some of them funny.

This clip was performed in front of a live audience for his special, Daniel Tosh: Happy Thoughts, and premiered on Comedy Central on 6 March 2011, with 3.25 million viewers. ${ }^{6}$

At least we're not women. Right fellas (laughter)? Geez, what is that like? Is it horrible? Is it awful? To know you're number two (laughter). By the way, these aren't my beliefs. These are my observations of the world I live in. If it changes, I'll adjust the material accordingly (laughter). I like when you try to rationalize it, "No it's great being a woman. Free drinks is worth not having equality (laughter).

Daniel Tosh's standup is tricky to analyse. As in all the cases discussed, there is the persona and the comedian. There is also the history of the comedian, which does not fix a pattern unalterably but does allow audiences to know what they are going to get and what kind of a persona/comedian they are going to watch. Daniel Tosh has evoked very strong responses: he (like many other comedians) has a bunch of followers who take him unironically and love him for his supercilious and hate filled persona; and, like many other comedians, he is hated for the self-same reasons. There are also, of course, people who get his irony and are taken by the sharpness of his critique; there are others, nonetheless, who get his irony and his critique, but are less than persuaded by his attitude towards the victims in his routines.

Deciding on what is or is not funny is a purely subjective judgment. In this clip, Tosh's remarks are met with laughter. The crucial contract between performer and audience, as 
already noted, is that the audience gives the performer licence, and can withdraw it at any time. There is plenty of laughter here.

He opens this routine by addressing the "fellas" in the audience. This speech act is designed to exclude anyone who is not included in we and fellas. Then he poses a question further designed to reinforce the polarization his first speech act has created, between fellas (not women) and women. Of course, there are women in the audience, so for the purpose of this address they are omitted, presumably to make the point about their status in the course of the persona's routine. The speech act as to what it is like to be a woman, sets the terms of the experience of being a woman: Is it horrible? Is it awful? The answer to such questions, if taken seriously as real questions could only be, "Yes it's horrible", or "No it's not horrible". Clearly this is a rhetorical question, the speech act being a clear directive that the answer is of course, "yes". How could it not be? At this point, his intention is to bring his whole audience on side: of course, it's horrible to be a woman, in those terms. His is not an information seeking question, it's simply a rhetorical device. Other options are closed. In examining this, one could argue that his intention here is to evoke an already bad situation (for the women in the audience) and exacerbate it for the purpose of reinforcing his point: it's horrible to be a woman. One could possibly, but not very successfully, argue that the performer's intention is to reinforce the men's sense of their own superiority, but Tosh is too skilled a performer for that to be his prime intention. To sidestep criticisms from various angles, Tosh claims he is talking about the world as it is. The speech act is a defensive one, designed to claim he is showing how hard it is to be a woman in the world as it is and that he is simply describing the world as he sees it. Then he talks very directly to the audience and it is unclear whether he is addressing the men or the women. The intention here is to scoff. "I like when you try to rationalize it." The strong implication is that this is the stupidest rationalization imaginable. "Free drinks is worth not having equality". The force of the speech act is ridicule: the question that hangs is who is he talking to? The men in the audience, the women? The deal he's outlining is of course ludicrous, but his greater point is that this is what seems to be happening in the world. There is likely to be some doubt as to what the overall speech act is here, depending on the point of view of a person or group of people in the audience, given that Tosh is a divisive figure among consumers of standup. The most charitable interpretation is probably that his intention is to goad the audience into recognition of this horrible, awful situation. However, this particular clip opens up a very complex debate about standup and social criticism. Persona and comedian are closely intertwined, as in many cases. It is not clear whether Daniel Tosh is speaking from the point of view of a privileged white man, who stands to lose nothing and in fact, perhaps stands to gain some too easy credibility for this routine. Do women want him to incite them to action, or simply to speak to the men in the audience?

\section{Conclusion}

In each of the examples we have covered, the comedian is fully aware of the terms of engagement. He or she enters into a place that on the face of it has more latitude than typical speech events. This latitude depends upon comic license. And license is the product of negotiation: between performer and audience, between communicating intention and having that intention realized. What Speech Act theory brings to the analysis of standup is a way to conceptualise license: itself a prodigiously difficult concept to explain. Think how often people struggle to explain why something is funny or not, or why something they think is funny can permissibly be said. As we have shown, the better comics understand the dynamics of the audience and play them, forming constituencies within them, pitting those 
constituencies against each other in some cases, and ultimately forcing individual audience members to question their own location within the broader political community.

The speech acts in standup comedy involve linguistic actions of enormous complexity. The audience has to navigate the distinction between the persona and the comedian, between the insult and the effect of the insult. They need to discern the difference between the proximate aim and the ultimate aim of the acts involved. As Austin might have said, communication is not about asserting truths even uncomfortable truths, it is about actions with social aims, in this case linguistic actions.

The question that is left hanging and requires a different kind of enquiry, much more difficult to conduct than the one we have attempted here is: can socially critical standup can have any noticeable effect on the attitudes or behaviour of both live and digitally mediated audiences? Can standup rouse the social consciousness and conscience of those who come to laugh?

\section{Notes}

${ }^{1}$ Within the body of literature on Speech Act theory, the scholarship of Grice, the neoGriceans and the Relevance Theorists has concentrated on the ways in which hearers are able to discern speaker intention (see for example, Grice (1989), Carston $(2004,2008)$, Sperber \& Wilson (1995), Horn (1984, 2004, 2005) and Levinson (2000).

2 The most widely explored of these are Michael Richards' (2006) rant at members of the audience who were talking during his show, Daniel Tosh's (2010) response to a woman who called him out on a rape joke and Joan Rivers' (2010) most professional handling of an audience member who objected to her joke involving deaf people.

${ }^{3}$ In the Joan Rivers' special, A Piece of Work, the work ethic and meticulous preparation is shown throughout, despite the seemingly impromptu nature of her stage performances.

${ }^{4}$ https://www.youtube.com/watch?v=aHlvvP8r4OY

${ }^{5} \mathrm{https}: / / \mathrm{www}$.youtube.com/watch?v=gfNhiRGQ-js

${ }^{6} \mathrm{http}: / /$ www.cc.com/video-clips/hb24rb/stand-up-daniel-tosh--number-two

\section{References}

Austin, J. L. (1962). How to Do Things with Words: The William James Lectures delivered at Harvard University in 1955, (eds.) J. O. Urmson \& Marina Sbisà, Oxford: Clarendon Press.

Carston, R. (2004).'Relevance Theory and the saying/implicating distinction'. In G. Ward \& L. Horn, Handbook of Pragmatics. Oxford, Blackwell, pp. 633-56.

Carston, R. (2008). The Pragmatics of Explicit Communication. Oxford: Blackwell.

Grice, H.P. (1975). 'Logic and conversation', Syntax and Semantics, vol.3 edited by P. Cole and J. Morgan, Academic Press. Reprinted as ch.2 of Grice 1989, pp. 22-40.

Grice, H.P. (1989). Studies in the Way of Words. Harvard University Press.

Horn, L. (1984). 'Toward a new taxonomy for pragmatic inference: Q-based and R-based implicature'. In Schiffrin, D. (ed.), Meaning, Form and Use in Context (GURT '84), pp. 11-42. Washington: Georgetown University Press.

Horn, L. (2004). 'Implicature'. In: Horn, L. \& Ward, G. (eds.) Handbook of Pragmatics. Oxford Blackwell, pp. 3-28.

Horn, L. (2005). 'Current issues in neo-Gricean pragmatics' Intercultural Pragmatics 2 6, pp. 191- 204. 
Horn, L. \& Ward, G. (eds.) (2004). Handbook of Pragmatics. Oxford: Blackwell.

Krefting, R. (2014). All joking aside: American humor and its discontents. Maryland: Johns Hopkins University Press.

Levinson, S. (2000). Presumptive Meanings: The Theory of Generalized Conversational Implicature. MIT Press.

Searle, J. (1969). Speech Acts: An Essay in the Philosophy of Language, Cambridge: Cambridge University Press

Searle, J. (1979). Expression and Meaning: Studies in the Theory of Speech Acts, Cambridge: Cambridge University Press, 1979.

Sperber, D. \& Wilson, D. (1995). Relevance: Communication and Cognition. Blackwell. Second edition.

\section{Audiovisual references}

Bruce, L. (1964). 'Are there any niggers here tonight?' https://www.youtube.com/watch?v=gfNhiRGQ-js accessed 2 October 2017.

Kondabolu, H. (2010). 'An honest moment in Aspen.' https://www.youtube.com/watch?v=aHlvvP8r4OY accessed 2 October 2017

Richards. M. (2006). 'Racial tirade against audience members.' Laugh Factory, California $6^{\text {th }}$ November, 2006. https://www.youtube.com/watch?v=VOtU6EjHjoY accessed 2 October 2017

Rivers. J. (2010). 'Joan Rivers takes on heckler in Wisconsin'. From Joan Rivers: A piece of work (dir. Sundberg \& Stern) https://www.youtube.com/watch?v=rAD-ky3TYQk accessed 1 October 2017.

Sundberg, A. \& R. Stern (dir.) (2010). Joan Rivers: A piece of work, USA: Breakthru Films. (Documentary Film).

Tosh, D. (July 2010). 'Wouldn't it be funny if that girl got raped by like, 5 guys right now? Like right now? What if a bunch of guys just raped her...'. Laugh Factory, Long Beach CA. (actual clip unavailable, quote attributed to Tosh).

Tosh. D. (2011). 'Happy thoughts. "At least we're not women, right fellas?"' Comedy Central, March 2011.http://www.cc.com/video-clips/hb24rb/stand-up-daniel-tosh--number-two accessed 1 October 2017

Vidale, T. (2002, August 2). 'The Tavis Smiley show' [Radio broadcast]. National Public Radio, USA. 